\title{
Study on the Eligibility of Introducing Hybrid-Drive Buses into the Public Passenger Transport
}

\author{
Janez Blaž1, ${ }^{*}$ - Samo Zupan² - Miha Ambrož2 \\ 1 Republic of Slovenia, Ministry of Infrastructure, Slovenia \\ 2 University of Ljubljana, Faculty of Mechanical Engineering, Slovenia
}

\begin{abstract}
The article presents the research related to the feasibility of introduction of alternative power source vehicles (hybrid system) into the public passenger transport (PPT) implemented as public service obligation of public passenger transport (PSO_PPT). The study examines and evaluates the existing implementation of 10 lines of PSO_PPT and implements the methods of mathematical calculations of the energy necessary to overcome the driving resistances of vehicles operating on these lines. The applied mathematical methods also include calculations of possible energy savings from implementing regenerative braking and a simulation of the reduction in air pollutant emissions. Furthermore the article presents the development of the experimental methods involving measurement of driving speeds, fuel consumption, altitude differences, number of brake applications as well as the time of braking during the bus ride along one of the observed lines in the pilot region. The results on the observed line were compared with mathematical calculations of the possible amount of energy regeneration. Based on the comparative analysis, we introduced the regeneration factor and used it to correct the previous mathematical calculations of the possible amount of energy regeneration due to braking on the other 9 lines in the selected pilot region. The final analysis has proven the eligibility of such research, which has demonstrated significant effects in energy savings (7\%) and the reduction of emissions (20 \%) in the pilot area.
\end{abstract}

Keywords: public passenger transport, hybrid drive, regeneration energy, air pollutant emissions

\section{Highlights}

- Introducing hybrid buses into the public passenger transport system could prove highly effective in ensuring energy regeneration and air pollutant emission reduction.

- $\quad$ The research has been conducted in the public service obligation of public passenger transport system, which is carried out in Slovenia with 1100 buses carrying around 48 million kilometres annually.

- Implementation of passenger transports is based on pre-defined infrastructure base with known elevation profiles, distances and pre-determined times, which were taken into account in these surveys.

- It is necessary to make theoretical calculations of the energy required to overcome all the driving resistance and the potential savings during braking and to carry out a comparison of these results with experimental data.

\section{INTRODUCTION}

Research on the use of environmentally friendly buses in Europe [1] shows that approximately $30 \%$ of registered buses meet the Euro I and II standard, slightly more than $30 \%$ of buses meet the Euro III standard and just a little more than $30 \%$ of buses meet the Euro IV and V or energy efficient vehicles (EEV) standard. As defined in the EU Strategies [2] and [3], the objective is to reduce greenhouse gas (GHG) emissions to be at least $60 \%$ lower than in the year 1990 and be firmly on the path towards zero. The operational program of measures to decrease GHG emissions by 2020 in Slovenia [4] sets as an objective that traffic emissions are to be reduced by $15 \%$ by 2030 compared to 2008 . Research in the field of alternative drives in buses shows that there are two different architectures suitable for hybrid vehicles - series and parallel architecture [5]. Research [6] shows the simulation of energy-conversion efficiency of hybrid drives, while research [7] shows the characteristics from the fuel economic point of view. In the parallel system, the internal combustion engine and electric motor are independently connected through transmission. In the series system, the internal combustion engine is connected to a generator which charges the battery through a controller. It then powers the electric motor or transmission as shown in Fig. 1 [8].

As a result of the previous research review and in terms of the characteristics of the implementation of the 10 lines of public service obligation of public passenger transport (PSO_PPT) in the selected pilot area we continued the research taking into account the engineering solutions of the bus drives with the serial hybrid drive system [9] and [10] and in-wheel electric motors [11].

Regarding the efficiency level in series hybrid versions, research [12] shows that transmission offers approximately $90 \%$ efficiency $\left(\eta_{t}\right)$, while the motor drive offers approximately $83 \%\left(\eta_{\mathrm{md}}\right)$ and the generator approx. $90 \%$ efficiency $\left(\eta_{\mathrm{g}}\right)$. Direct 
efficiency between the internal combustion engine and the generator thus equals approximately $67 \%$. Research on the efficiency, which directly results from braking regeneration [13] shows that the level of efficiency ranges between $20 \%$ and $42 \%$. Fig. 2 shows the conditions of the regeneration of the energy achieved through braking.

The driving behaviour plays a significant role in this regard. Eco driving [13] recaptured almost $42 \%$ of the energy. The estimated mean value $\left(\eta_{\mathrm{rb}}\right)$ is approx. $30 \%$. Total regeneration efficiency $\left(\eta_{\text {rtot }}\right)$ is thus:

$$
\eta_{\mathrm{rtot}}=\eta_{\mathrm{t}} \cdot \eta_{\mathrm{md}} \cdot \eta_{\mathrm{g}} \cdot \eta_{\mathrm{rb}}
$$

The entire research structure consists of analytical and experimental work. The analytical part (Section 1) describes the parameters that were used in the calculations for all 10 lines and whose meaning and values are shown in Table 2. The structure of the performance of the experiment is shown on one of these 10 lines. In Section 1.1. we present the equations we used to calculate the energy needed to overcome the driving resistances of a bus driving on a bus line, as well as the possible energy savings due to regenerative braking. In the following, we present the final result tables for all 10 lines calculated for a single journey

a)

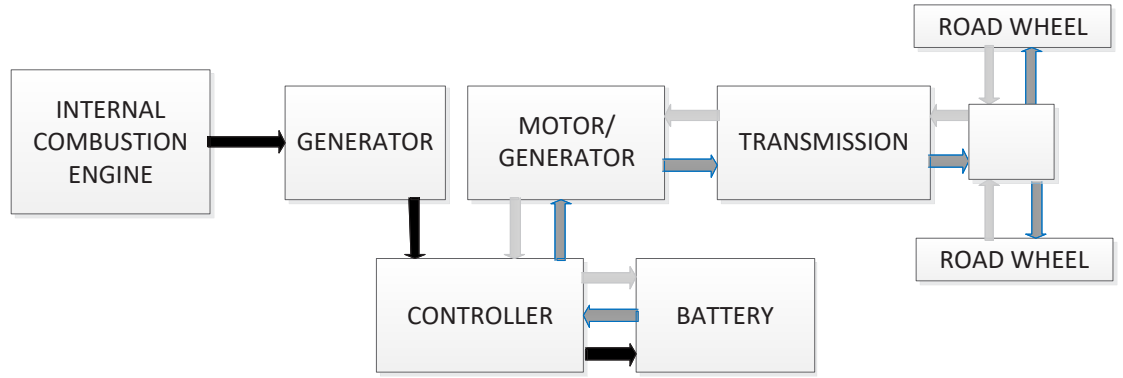

b)

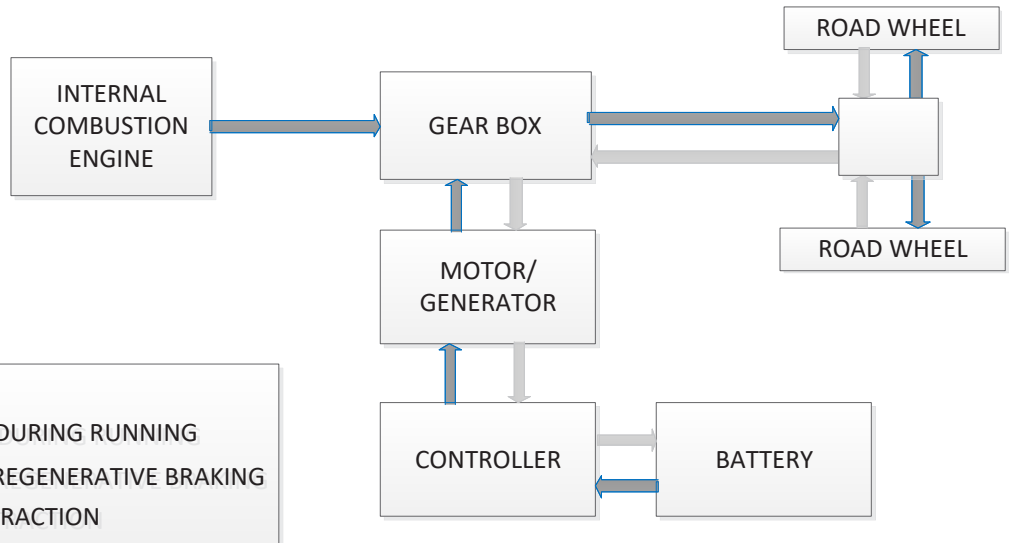

Fig. 1. Two different architectures suitable for hybrid vehicles - a) series and b) parallel (re-drawn from [8])
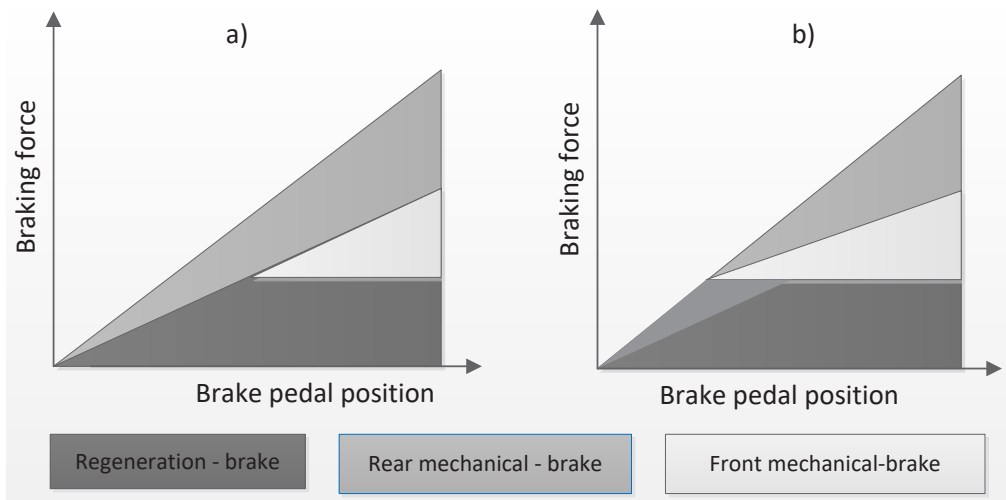

Fig. 2. Generation of the regenerative energy through braking; a) hard, and b) soft braking (Re-drawn from [13]) 
and at the annual level. Calculations are also made to investigate the reduction of pollutant emissions by using hybrid-drive buses.

\section{WORKING METHODOLOGY AND CONDUCT OF THE EXPERIMENT}

In view of the aforementioned need for research, the Banjšice Plateau near Nova Gorica with a characteristic hilly landscape was selected as the pilot area with the most suitable relief characteristics. Ten bus lines (Table 1) of the PSO_PPT operate on the area. The operator is professional bus company, which was awarded a concession by the Slovenian public transport authority (PTA), i.e. the Ministry of Infrastructure. The map of the pilot area with the bus lines as per Table 1, is shown in Fig. 3.

In the analytical part of the research, simulations and calculations were performed to overcome the following resistances during the bus traveling along the lines on the pilot area: rolling resistance, aerodynamic resistance, slope resistance and inertia mass resistance. We calculated the total energy required to overcome all the resistances (TEOR) and the energy saving potential of regenerative braking (ESPRB) [14] and [8].

To enable calculations, a necessary basis was first provided based on the geographical features of each bus line [15]. For those segments, the slope inclinations and the route lengths were determined. Among the 10 selected lines included in the research, the measurements, i.e. the experimental part, were performed on Line_6, by acquiring and storing the vehicle diagnostic data from the vehicle controller area network (CAN) bus connector (Fig. 4). In accordance with the SAE J1939 protocol [16], the operating

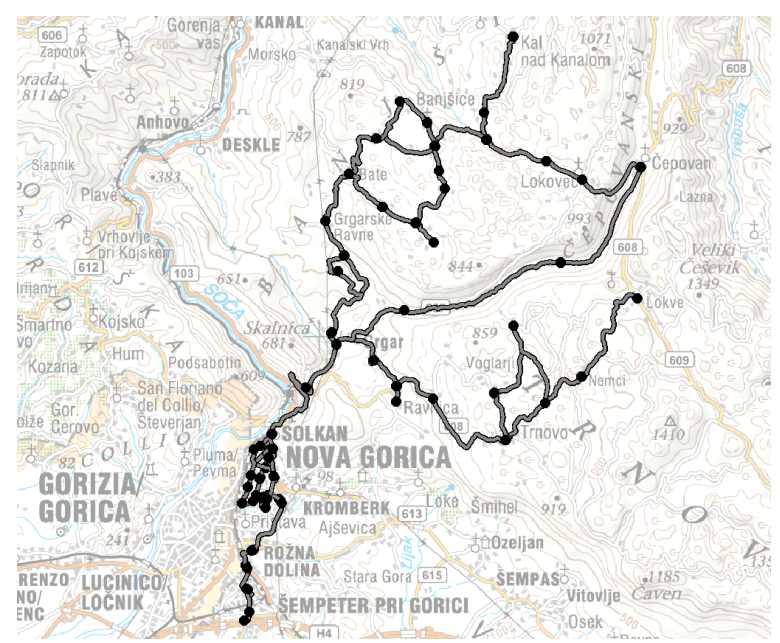

Fig. 3. Map of bus lines and station points on the pilot area

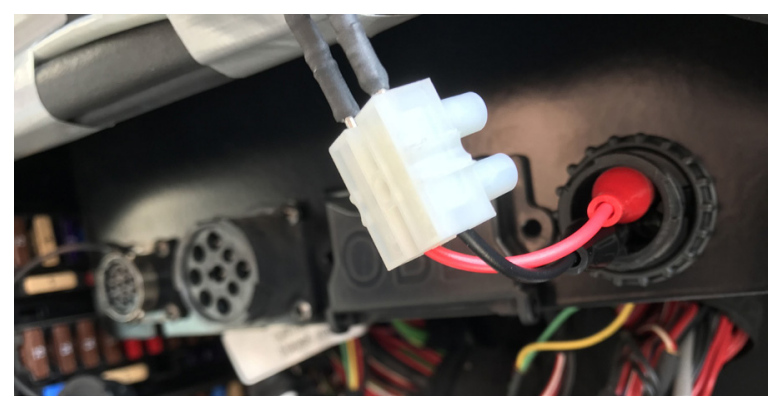

Fig. 4. Connection of the computer interface probes to the vehicle CAN bus

parameter values were obtained as presented and marked in Table 2. The time history of the following values was significant: vehicle speed, detection of the brake switch and fuel rate (Fig. 5). The bus stop locations were manually added to the $\log$ file by the

Table 1. List of bus lines in the characteristic pilot area

\begin{tabular}{cclccc}
\hline No. & Designation & Line & Length $[\mathrm{km}]$ & No. of bus stops & Travel time* $^{*}$ \\
\hline 1 & Line_1 & Nova Gorica - Čepovan & 35 & 19 & $1 \mathrm{~h} 5 \mathrm{~min}$ \\
\hline 2 & Line_2 & Čepovan - Šempeter pri Gorici & 31 & 20 & $1 \mathrm{~h} 4 \mathrm{~min}$ \\
\hline 3 & Line_3 & Nova Gorica - Lokve & 23 & 12 & $47 \mathrm{~min}$ \\
\hline 4 & Line_4 & Grgar - Šempeter pri Gorici & 13 & 14 & $29 \mathrm{~min}$ \\
\hline 5 & Line_5 & Grgar - Nova Gorica & 39 & 33 & $1 \mathrm{~h} \mathrm{50} \mathrm{min}$ \\
\hline 6 & Line_6 & Lokve - Nova Gorica & 31 & 20 & $1 \mathrm{~h} 12 \mathrm{~min}$ \\
\hline 7 & Line_7 & Nova Gorica - Kal nad Kanalom & 30 & 13 & $55 \mathrm{~min}$ \\
\hline 8 & Line_8 & Nova Gorica - Nova Gorica & 36 & 22 & $1 \mathrm{~h} \mathrm{17} \mathrm{min}$ \\
\hline 9 & Line_9 & Banjšice - Nova Gorica & 36 & 17 & $1 \mathrm{~h} \mathrm{3} \mathrm{min}$ \\
\hline 10 & Line_10 & Grgar - Nova Gorica & 39 & 33 & $1 \mathrm{~h} \mathrm{50} \mathrm{min}$ \\
\hline
\end{tabular}

* The values of planned travel times on bus lines are taken from the applicable register of timetables within the Slovenian PSO_PPT system and relate to a single journey, yet are subject to the itinerary of a specific journey and other traffic factors. 
operator. Measurements of the elevation profile of the driving route were performed with a GNSS device and synchronized with other measurements based on recorded measurement times. In the CAN messages, speed and fuel rate values are recorded as calculation values, while detection of the brake application is recorded as a bit sequence. Identification marks of the CAN messages for the individual quantities are explained in Table 2.

Throughout the entire measurement process for this bus line, the results were recorded in an electronic spreadsheet with 75,884 time intervals, which enabled

Table 2. Input parameters in the analytical model and measurement evaluation model

\begin{tabular}{|c|c|c|c|c|c|}
\hline Parameter & Meaning & Unit & Values from & Values to & Source \\
\hline$R_{\mathrm{SUM}}$ & Sum of resistances & {$[\mathrm{N}]$} & $-29,381.63$ & $64,720.80$ & Eq. (2) \\
\hline$R_{\mathrm{R}}$ & Rolling resistance & {$[\mathrm{N}]$} & $1,805.33$ & $2,049.80$ & Eq. (3) \\
\hline$R_{\mathrm{A}}$ & Aerodynamic resistance & {$[\mathrm{N}]$} & 0 & 248.25 & Eq. (4) \\
\hline$R_{\mathrm{S}}$ & Slope resistance & {$[\mathrm{N}]$} & $-29,381.63$ & $64,720.80$ & Eq. (5) \\
\hline$R_{\mathrm{I}}$ & Inertia mass resistance & {$[\mathrm{N}]$} & $-11,993.73$ & $11,993.73$ & Eq. (6) \\
\hline$m$ & Mass of the vehicle and passengers & {$[\mathrm{kg}]$} & 12,430 & 13,930 & Bus company and weighing \\
\hline$g$ & Gravitational acceleration & {$\left[\mathrm{m} / \mathrm{s}^{2}\right]$} & 9.81 & 9.81 & \\
\hline$\alpha_{\mathrm{i}}$ & Slope inclination & {$\left[^{\circ}\right]$} & -12.42 & 28.27 & $\begin{array}{l}\text { Analyses of the elevation profile of } \\
\text { bus lines }\end{array}$ \\
\hline$v_{\mathrm{i}}$ & Vehicle speed & {$[\mathrm{m} / \mathrm{s}]$} & 0 & 17.83 & $\begin{array}{l}\text { SAE J1939 message: } 18 \mathrm{FEF} 100 \\
\text { CCVS Cruise Control/Wheel-based } \\
\text { vehicle Speed, byte } 2 \text { and } 3\end{array}$ \\
\hline$w_{\mathrm{i}}$ & Wind speed against vehicle & {$[\mathrm{m} / \mathrm{s}]$} & 0 & 0 & \\
\hline$\rho_{\mathrm{A}}$ & Density of surrounding air & {$\left[\mathrm{kg} / \mathrm{m}^{3}\right]$} & 1.25 & 1.25 & {$[14]$} \\
\hline$c_{\mathrm{w}}$ & Aerodynamical drag coefficient & {$[-]$} & 0.65 & 0.65 & {$[14]$} \\
\hline$A$ & Vehicle frontal area & {$\left[\mathrm{m}^{2}\right]$} & 6.24 & 6.24 & Bus type-approval certificate \\
\hline$\delta$ & Inertia mass coefficient & {$[-]$} & 1.05 & 1.05 & \\
\hline$t_{\mathrm{i}}$ & $\begin{array}{l}\text { Acceleration/deceleration time (when braking or } \\
\text { stopping) }\end{array}$ & {$[s]$} & 0 & 11.712 & $\begin{array}{l}\text { Determined from the difference } \\
\text { in the speed of the experimental } \\
\text { bus drive }\end{array}$ \\
\hline TEOR & $\begin{array}{l}\text { Total energy required for a single bus journey on } \\
\text { the line }\end{array}$ & {$[\mathrm{kWh}]$} & 21.59 & 55.89 & Eq. (7) \\
\hline$T E O R_{\mathrm{y}}$ & Total energy required for all bus journeys per year & {$[\mathrm{kWh}]$} & $4,385.23$ & $42,292.37$ & PTA Register of bus lines \\
\hline$\left(s_{\mathrm{i}}-s_{\mathrm{i}-1}\right)$ & $\begin{array}{l}\text { The length of the concerned itinerary segment on } \\
\text { the observed line }\end{array}$ & {$[\mathrm{m}]$} & 0 & 295.8 & $\begin{array}{l}\text { Analyses of the elevation profile of } \\
\text { bus lines }\end{array}$ \\
\hline$s_{\mathrm{j}}, s_{\mathrm{n}}$ & $\begin{array}{l}\text { Distance needed for acceleration/deceleration at } \\
\text { bus stops }\end{array}$ & {$[\mathrm{m}]$} & 41.839 & 41.839 & $\begin{array}{l}\text { Determined based on the } \\
\text { average stopping times from the } \\
\text { experimental part }\end{array}$ \\
\hline$E S P R B$ & $\begin{array}{l}\text { The energy saving potential of regenerative } \\
\text { braking for a single bus journey on the line }\end{array}$ & {$[\mathrm{kWh}]$} & 5.24 & 44.84 & Eq. (8) \\
\hline$E S P R B_{\mathrm{y}}$ & $\begin{array}{l}\text { The energy saving potential of regenerative } \\
\text { braking for all bus journeys per year }\end{array}$ & {$[\mathrm{kWh}]$} & $3,579.51$ & $11,544.75$ & PTA Register of bus lines \\
\hline$K_{\text {reg }}$ & Regeneration coefficient & {$[-]$} & 1.742 & 1.742 & $\begin{array}{l}\text { Calculated from the analytical and } \\
\text { experimental part (Section 1) }\end{array}$ \\
\hline$\eta_{\text {rtot }}$ & Total regeneration efficiency & {$[-]$} & 0.201 & 0.201 & Eq. (1) \\
\hline$F R$ & Fuel rate & {$[\mathrm{l} / \mathrm{h}]$} & 0 & 60.7 & $\begin{array}{l}\text { SAE J1939 message: } 18 \text { FEF200 } \\
\text { FE Fuel economy, byte } 1 \text { and } 2\end{array}$ \\
\hline$B S$ & Brake switch & {$[-]$} & 0 & 1 & $\begin{array}{l}\text { SAE J1939 message: } 18 \mathrm{FEF} 100 \\
\text { CCVS Cruise Control/Wheel-based } \\
\text { vehicle Speed, byte } 4\end{array}$ \\
\hline$\eta_{\mathrm{t}}$ & Transmission efficiency & {$[-]$} & 0.9 & 0.9 & {$[12]$} \\
\hline$\eta_{\mathrm{md}}$ & Motor drive efficiency & {$[-]$} & 0.83 & 0.83 & {$[12]$} \\
\hline$\eta_{\mathrm{g}}$ & Generator efficiency & {$[-]$} & 0.9 & 0.9 & [12] \\
\hline$\eta_{\mathrm{rb}}$ & Regeneration braking efficiency & {$[-]$} & 0.2 & 0.42 & [13] \\
\hline
\end{tabular}


the reading of 151 cases of brake switch activation. Based on the data on speed changes during brake switch, calculations were made of kinetic energy and deceleration changes, which were then used in subsequent calculations of the regeneration coefficient. Based on the time history of the vehicle speed, numerical differentiation over time was applied to obtain data on the average deceleration value, which were then used to calculate the necessary braking distances and stopping times.

The results of these calculations were used in further research analyses. The total sum of kinetic energy changes during all 151 braking cases which could be used for ESPRB, amounts to $9.39 \mathrm{kWh}$. In the theoretical (analytical) part based on the equations of resistance sums, we obtained the calculated size of $E S P R B$ on the same line, equals $5.39 \mathrm{kWh}$. From the values of the experimental $(9.39 \mathrm{kWh})$ and analytical ESPRB (5.39 kWh), we obtained a quotient, which we named a regeneration coefficient $\left(K_{\text {reg }}\right)$, the value of which is 1.742 . In the analytical part, calculations were made taking into account the simulation of the conditions of the braking at 20 station points. Since the analytical part of calculations was performed on all 10 bus lines and the experimental part only on one line, the calculated regeneration coefficient $K_{\text {reg, was }}$ used in the calculation on all other bus lines in the pilot area, as shown in Eq. (8).

Table 2 presents the input parameters which were used in the research described in this paper, whereby parameter values refer to the processed data on all 10 bus lines. To determine the mass of the vehicle together with the passengers, a special weighing method was applied. The plus and the minus sign before the slope angle denotes the bus ascending (+ sign) or descending (- sign) a slope.

\subsection{Calculation Methodology}

During the vehicle movement along the roadway, driving resistances appear which impede vehicle motion, meaning the resistances are in the opposite direction from vehicle motion. Landscape configuration in the pilot area with many ascents and descents results in "negative resistances" which are in the direction of vehicle motion and occur mainly when the vehicle is descending a slope. All "negative resistances" present the possibility for energy regeneration available to vehicles with an alternative drive (hybrid vehicles). In this way, the sum of resistances $\left(R_{\mathrm{SUM}}\right)$ was calculated which consists of the rolling resistance, aerodynamic resistance, slope

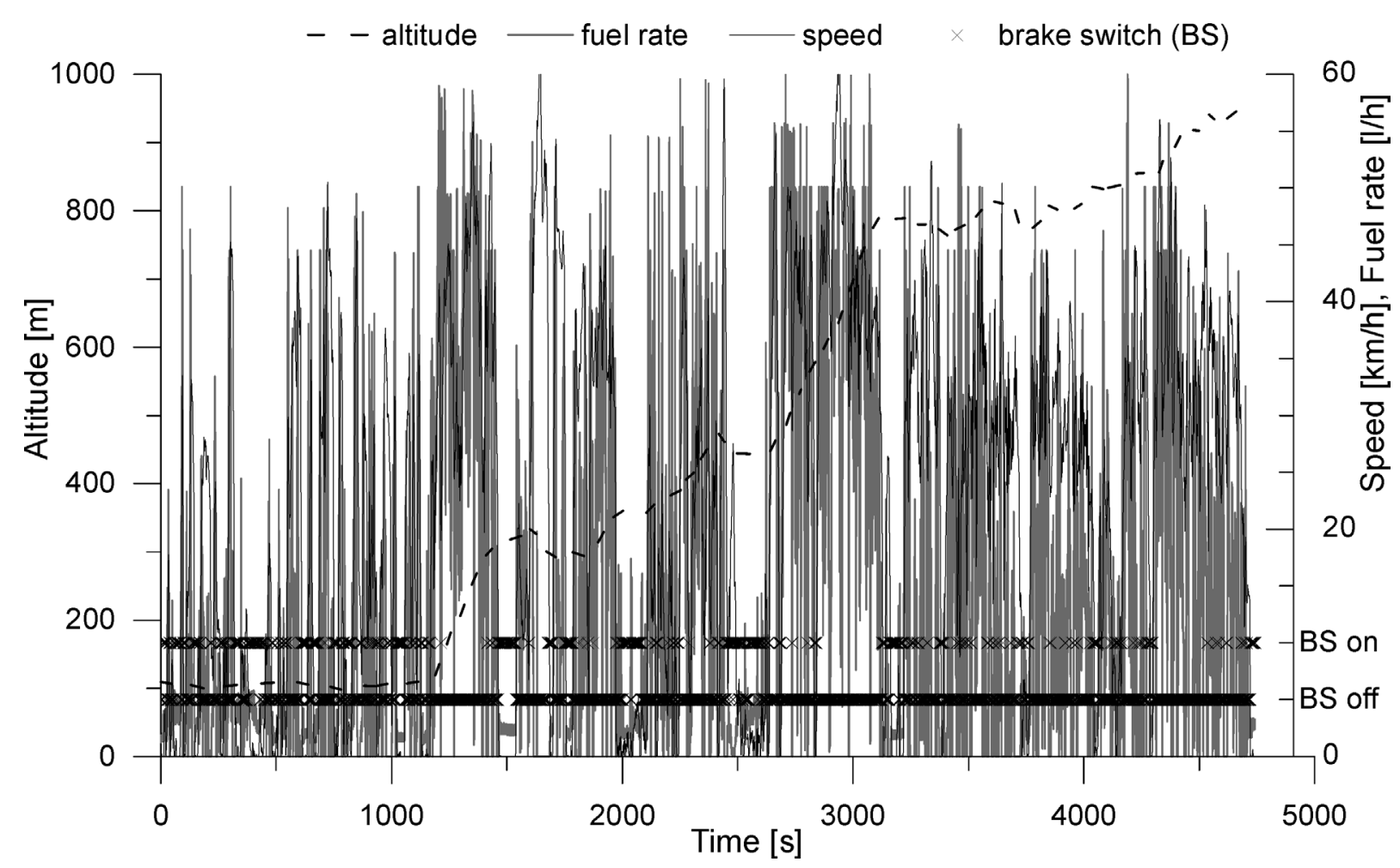

Fig. 5. Diagram of the measurements performed on Line_6: elevation profile, vehicle speed, fuel rate and brake switch 
resistance and inertia mass resistance. The quantities used in calculation, their symbols and explanations are summarised in Table 2.

\subsubsection{Calculation of the Sum of Resistances}

The sum of driving resistances on all itinerary segments is calculated as follows:

$$
R_{\mathrm{SUM}}=\sum_{i}\left(R_{\mathrm{R} i}+R_{\mathrm{A} i}+R_{\mathrm{S} i}+R_{\mathrm{I} i}\right) .
$$

The rolling resistance on the $i^{\text {th }}$ segment of the observed line is determined as:

$$
R_{\mathrm{R} i}=m \cdot g \cdot f \cdot \cos \alpha_{i}
$$

The aerodynamic resistance on the $i^{\text {th }}$ segment of the observed line is calculated as follows:

$$
R_{\mathrm{A} i}=\frac{\rho_{\mathrm{A}} \cdot A \cdot\left(v_{i}-w_{i}\right)^{2} \cdot c_{\mathrm{w}}}{2} .
$$

The slope resistance on the $i^{\text {th }}$ segment is determined by the following equation:

$$
R_{\mathrm{Si}}=m \cdot g \cdot \sin \alpha_{i} .
$$

Overcoming the inertia mass resistance on the $i^{\text {th }}$ segment of the observed line is calculated as follows:

$$
R_{\mathrm{I} i}=\frac{m \cdot \delta \cdot v_{i}}{t_{i}} .
$$

\subsubsection{Total Energy Required to Overcome all the Resistance} (TEOR)

$$
T E O R=\sum_{i}\left(\left(R_{\mathrm{R} i}+R_{\mathrm{A} i}+R_{\mathrm{S} i}\right) \cdot\left(s_{i}-s_{i-1}\right)\right)+\sum_{j}\left(R_{\mathrm{I} i} \cdot s_{j}\right) .
$$

\subsubsection{Calculation Energy Saving Potential of Regenerative Braking (ESPRB)}

$$
E S P R B=\left(\sum_{k} T E O R_{k}+\sum_{n}\left(R_{\mathrm{II}} \cdot s_{n}\right)\right) \cdot K_{\mathrm{reg}} \cdot
$$

$\sum_{k}$ TEOR $_{k}$ is calculated energy saving potential of regenerative braking as the sum of only negative values of the required energy, those who, acting on the basis of the calculated forces of resistance, act in the direction of motion of the vehicle and offer the possibility of regeneration.

$\sum_{n}\left(\mathrm{R}_{I n} \cdot s_{n}\right)$ is calculated regeneration energy only when braking the bus prior to arrival at station point and which is not included in the previous calculation of TEOR.

Table 3 presents the comparison of the results obtained from the calculations based on elevation profiles and described equations by taking account of the regeneration coefficient determined through the experimental part measurements performed on Line 6.

\section{ANALYSIS OF THE RESULTS AND DISCUSSION}

Calculation results for the 10 observed bus lines are presented in Table 3. The analysis of the results shows that the values of all selected lines are widely spread. This is due to different driving regimes on individual lines, which results from different positive and negative slope inclinations. Therefore, the calculations were also made on an annual basis for all bus journeys on the selected bus lines. On all 10 observed lines, $126,540 \mathrm{~km}$ are operated per year, which requires 199.4 MWh energy (TEOR) to overcome all the

Table 3. Calculation results and possible regeneration percentage

\begin{tabular}{cccrrrrr}
\hline $\begin{array}{c}\text { Line } \\
\text { no. }\end{array}$ & $\begin{array}{c}\text { Distance travelled/ } \\
\text { journey }[\mathrm{km}]\end{array}$ & $\begin{array}{c}\text { TEOR/journey } \\
{[\mathrm{kWh}]}\end{array}$ & $\begin{array}{c}\text { ESPRB/journey } \\
{[\mathrm{kWh}]}\end{array}$ & $\begin{array}{c}\text { Distance travelled/ } \\
\text { year }[\mathrm{km}]\end{array}$ & $\begin{array}{c}\text { TEOR/year } \\
{[\mathrm{kWh}]}\end{array}$ & $\begin{array}{c}\text { ESPRB/year } \\
{[\mathrm{kWh}]}\end{array}$ & $\begin{array}{c}\text { Rate: } \\
\text { ESPRB/TEOR }[\%]\end{array}$ \\
\hline 1 & 35 & 54.61 & 24.82 & 12,000 & $18,203.33$ & $8,273.33$ & 45.45 \\
\hline 2 & 31 & 49.69 & 13.48 & 23,280 & $37,315.59$ & $10,123.05$ & 27.13 \\
\hline 3 & 23 & 48.90 & 5.24 & 18,900 & $40,183.04$ & $4,305.91$ & 10.72 \\
\hline 4 & 13 & 21.59 & 8.43 & 5,520 & $9,167.45$ & $3,579.51$ & 39.05 \\
\hline 5 & 39 & 39.89 & 41.10 & 5,880 & $6,014.18$ & $6,196.62$ & 103.03 \\
\hline 6 & 31 & 55.89 & 9.39 & 13,600 & $24,519.48$ & $4,119.48$ & 16.80 \\
\hline 7 & 30 & 47.77 & 13.04 & 26,560 & $42,292.37$ & $11,544.75$ & 27.30 \\
\hline 8 & 36 & 47.77 & 32.00 & 9,400 & $12,473.28$ & $8,355.56$ & 66.99 \\
\hline 9 & 36 & 24.46 & 44.84 & 7,200 & $4,892.00$ & $8,968.00$ & 183.32 \\
\hline 10 & 39 & 40.72 & 42.31 & 4,200 & $4,385.23$ & $4,556.46$ & 103.90 \\
\hline Summary: & & \multicolumn{7}{c}{126,540} & $199,445.96$ & $70,022.66$ & 35.11 \\
\hline Calculation of the ESPRB taking into account total regeneration efficiency $\left(\eta_{\mathrm{rtot}}\right)=0.201$ & Eq. $(1)$ & $14,074.56$ & 7.06 \\
\hline
\end{tabular}


resistances. The ESPRB equals $70 \mathrm{MWh}$, which is $35.11 \%$ of TEOR energy. Based on the available data on regeneration efficiency [12] and [13], the calculated values are reduced by the total regeneration efficiency $\eta_{\text {rtot}}$, as shown in Eq. (1). It therefore follows that on the selected bus lines, 14.1 MWh of regenerated $E S P R B$ energy could be used on an annual basis, which presents $7.1 \%$ of the TEOR energy needed to overcome all the resistances.

Comparative analyses are also shown in Fig. 6. The results show that the lines with the highest ratio between descents and ascents indicate the highest regeneration rate. It is noted that the best results are obtained from the lines where ascents and descents mostly alternate.

Analyses have also been performed of the amount of emissions in the pilot area on an annual basis, assuming that on all bus routes only diesel and hybrid buses are used (Table 4). The results are based on the measurements of a bus company with a concession in Flanders, Belgium [17] and [18], whereby the following average values are taken account of: fuel consumption monitoring, compliance with the applicable emission standards, use of diesel-hybrid buses where possible and use of alternative fuels. Also emphasized is the fact that all bus drivers completed an eco-driving training. The research presented in [17] and [18] indicates emission values in tank to wheel (TTW) (contrary to well to tank (WTT) or well to wheel $(W T W=W T T+$ $T T W$ ) conditions and compares emission values of a conventional diesel bus and hybrid bus. On average, hybrid buses produce $20 \%$ less emissions compared to conventional diesel buses, as shown in Table 4. Analysis of emission values for different hybrid bus technologies is presented in literature [19], whereas literature [20] indicates that hybrid buses provide an average of approx. $20 \%$ reduction in GHG emissions compared to conventional diesel buses. The research presented in [21] presents the vehicle emission model for road transport that takes account of three models which differ in vehicle interaction with characteristic driving style (especially in regard to vehicle speed) and determined emission values.

TEOR [kWh] ESPRB [kWh] RATE: ascent/descent [\%]

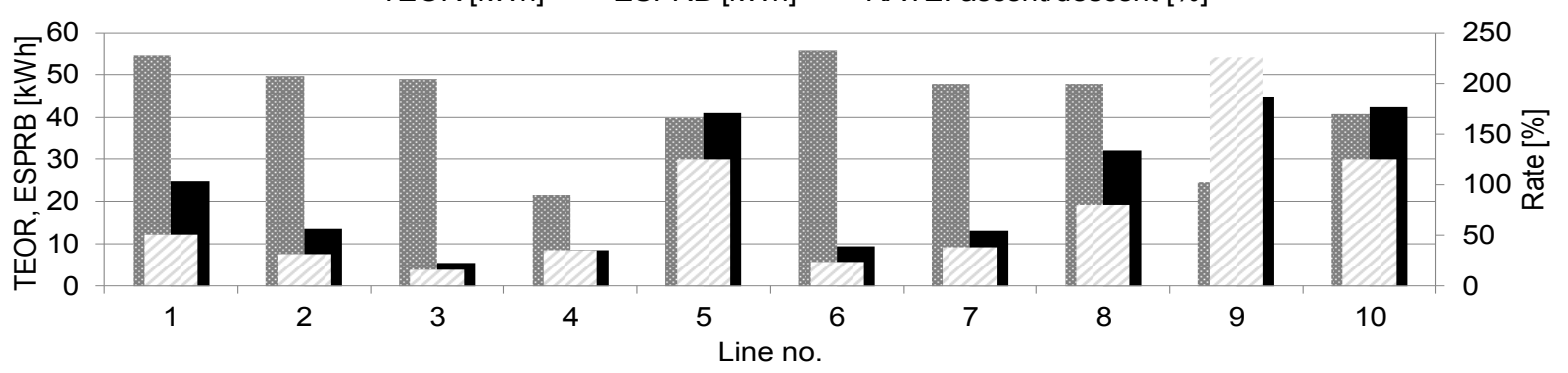

Fig. 6. Comparison of results obtained on the selected bus lines of the pilot area

Table 4. Comparison of results obtained on the selected bus lines of the pilot area

\begin{tabular}{ccccccccc}
\hline $\begin{array}{c}\text { Line } \\
\text { no. }\end{array}$ & $\begin{array}{c}\text { Distance } \\
\text { travelled/journey } \\
{[\mathrm{km}]}\end{array}$ & $\begin{array}{c}\text { Distance } \\
\text { travelled/year } \\
{[\mathrm{km}]}\end{array}$ & $\begin{array}{c}\text { Conv. diesel } \\
\mathrm{CO}_{2} \text { emission } \\
{[\mathrm{t}]}\end{array}$ & $\begin{array}{c}\text { Conv. diesel } \\
\text { PM emission } \\
{[\mathrm{kg}]}\end{array}$ & $\begin{array}{c}\text { Conv. diesel } \\
\text { NOx emission } \\
{[\mathrm{kg}]}\end{array}$ & $\begin{array}{c}\text { Hybrid } \mathrm{CO}_{2} \\
\text { emission } \\
{[\mathrm{t}]}\end{array}$ & $\begin{array}{c}\text { Hybrid PM } \\
\text { emission } \\
{[\mathrm{kg}]}\end{array}$ & $\begin{array}{c}\text { Hybrid NOx } \\
\text { emission } \\
{[\mathrm{kg}]}\end{array}$ \\
\hline 1 & 35 & 12,000 & 12.68 & 0.96 & 144.00 & 10.15 & 0.77 & 115.20 \\
\hline 2 & 31 & 23,280 & 24.61 & 1.86 & 279.36 & 19.69 & 1.49 & 223.49 \\
\hline 3 & 23 & 18,900 & 19.98 & 1.51 & 226.80 & 15.99 & 1.21 & 181.44 \\
\hline 4 & 13 & 5,520 & 5.83 & 0.44 & 66.24 & 4.67 & 0.35 & 52.99 \\
\hline 5 & 39 & 5,880 & 6.22 & 0.47 & 70.56 & 4.97 & 0.38 & 56.45 \\
\hline 6 & 31 & 13,600 & 14.38 & 1.09 & 163.20 & 11.51 & 0.87 & 130.56 \\
\hline 7 & 30 & 26,560 & 28.07 & 2.12 & 318.72 & 22.47 & 1.70 & 254.98 \\
\hline 8 & 36 & 9,400 & 9.94 & 0.75 & 112.80 & 7.95 & 0.60 & 90.24 \\
\hline 9 & 36 & 7,200 & 7.61 & 0.58 & 86.40 & 6.09 & 0.46 & 69.12 \\
\hline 10 & 39 & 4,200 & 4.44 & 0.34 & 50.40 & 3.55 & 0.27 & 40.32 \\
\hline Summary: & 126,540 & 133.75 & 10.12 & 1518.48 & 107.05 & 8.10 & 1214.78 \\
\hline Rate of hybrid / conventional diesel: & & & & & 0.80 & 0.80 & 0.80 \\
\hline
\end{tabular}




\section{CONCLUSIONS}

Based on the aforementioned researches, the following conclusions can be made:

1) The PTA has the obligation to monitor implementation of the public passenger transport by taking account of: fleet properties in the PSO_PPT system, driving mode, landscape configuration, distance travelled, etc. as well as to perform optimization also in the field of energy regeneration and emission reduction in accordance with the applicative European and national guidelines. In order to realize this, the studies presented in this article (Tables 3 and 4) show simulations of such effects.

2) The eligibility of the aforementioned research is based on comparative analyses the results of which indicate that on the selected pilot area, which represents a percentage share of $0.8 \%$ of the overall PSO PPT operation performed by concessionaire and $0.28 \%$ of the overall PSO_PPT operation performed by all the concessionaires in the Republic of Slovenia.

It should also be taken into consideration that the investment costs of introducing such hybrid buses are according to literature [19], $40 \%$ higher than those for conventional buses. The literature indicates that the operating costs for a conventional diesel bus are $0.82 € / \mathrm{km}$ and for a diesel hybrid bus $0.75 € / \mathrm{km}$. The replacement costs for the energy storage system are also to be taken into consideration as they account for approximately $25 \%$ of the total operating costs for hybrid buses and $50 \%$ for electric buses. Based on these calculations, it is recommended that additional analyses be made to assess the possibilities of a government or local community subsidized purchase of buses with alternative fuel or hybrid drives.

It is our recommendation that similar and detailed research as well as measurements be continued also in other characteristic areas (high-speed lines, city lines) so as to enable maximum quality of the necessary data. This research presents a basis for the formation of tender specifications in introducing hybrid buses into the public transport in Slovenia. In accordance with the tender specifications, the PTA of Ministry of Infrastructure may require the use of a certain percentage of hybrid buses during the transitional period as well as offer different (financial) incentives to those concessionaires who will purchase hybrid buses and use them in the PSO_PPT system. It is therefore important that the Ministry of Infrastructure takes a position on this matter as soon as possible due to statutory deadlines according to which new concession contracts are to be signed based on prior public tenders in 2019.

\section{ACKNOWLEDGEMENT}

The research presented in this article has been partly funded by the Slovenian Research Agency as part of the "Modelling in technics and medicine" (code P20109 (C)) research programme.

The authors also express their gratitude to the bus company Nomago, d.o.o. (www.nomago. si), who kindly provided the bus and the driver for measurements.

\section{REFERENCES}

[1] Corazza, M.V., Guida, U., Musso, A., Tozzi, M. (2016). A European vision for more environmentally friendly buses. Transportation Research Part D: Transport and Environment, vol. 45, p. 48-63, D0l:10.1016/j.trd.2015.04.001.

[2] European Commission, Energy, Climate change, Environment, Climate action, from https://ec.europa.eu/clima/policies/ transport_en, accessed on 2018-03-30.

[3] Communication from the commission to the European Parliament, the Council, the European Economic and Social Committee and the Committee of the Regions-\{SWD(2016) 244 final\} (2016). A European Strategy for Low-Emission Mobility. European Commission, Brussels.

[4] Ministry of Environment and Spatial Planning: Operational program of measures to reduce greenhouse gas emissions by 2010, from http://www.mop.gov.si/fileadmin/mop.gov. si/pageuploads/zakonodaja/varstvo_okolja/operativni_ programi/optgp2020.pdf, accessed on 2018-30-3. (in Slovene)

[5] Ranganathan, S (200/). Hybrid buses costs and benefits, from http://www.eesi.org/files/eesi_hybrid_bus_032007.pdf, accessed on 2018-04-10, EESI, Washington DC.

[6] Katrašnik, T., Trenc, F., Oprešnik, S.R. (2007). Study of the energy-conversion efficiency of hybrid powertrains. Strojniški vestnik - Journal of Mechanical Engineering, vol. 53, no. 10, p. 667-682.

[7] Katrašnik, T. (2010). Fuel economy of hybrid electric heavyduty vehicles. Strojniški vestnik - Journal of Mechanical Engineering, vol. 56, no. 12, p. 791-802.

[8] Cole, D.A. (2016). The Effectiveness of Energy Storage in Hybrid Vehicles. University of the West of England, Bristol.

[9] Melo, P., Ribau, J., Silva, C. (2014). Urban bus fleet conversion to hybrid fuel cell optimal powertrains, Procedia - Social and Behavioral Sciences, vol. 111, p. 692-701, D0I:10.1016/j. sbspro.2014.01.103.

[10] Nurhadi, L., Borén, S., Ny, H. (2014). Advancing from efficiency to sustainability in Swedish medium - sized cities: an approach for recommending powertrains and energy carriers for public transport systems, Procedia - Social and Behavioral Sciences, vol. 111, p. 1218-1225, Dol:10.1016/j. sbspro.2014.03.723. 
[11] Mihály, A., Gáspár, P., Németh, B. (2017). Robust faulttolerant control of in-wheel driven bus with cornering energy minimization. Strojniški vestnik - Journal of Mechanical Engineering, vol. 63, , no. 1, p. 35-44, Dol:10.5545/svjme.2016.3639.

[12] Ehsani, M., Gao, Y., Gay, S.E., Emadi, A. (2005). Modern Electric, Hybrid Electric, and Fuel Cell Vehicles. CRC Press LLC, Boca Raton.

[13] Xiano, B., Lu, H., Wang, H., Ruan, J., Zhang, N. (2017). Enhanced regenerative braking strategies for electric vehicles: Dynamic performance and potential analysis. Energies, p. 1-19, Dol:10.3390/en10111875.

[14] Zupan, S., Ambrož, M. (2017). Vehicles. University of Ljubljana, Faculty of Mechanical Engineering, Ljubljana. (in Slovene)

[15] Ambrož, M., Korinšek, J., Blaž, J., Prebil, I. (2016). Integral management of public transport. $6^{\text {th }}$ Transportation Research Procedia, vol. 14, p. 382-391, D0l:10.1016/j. trpro.2016.05.090.

[16] Surface Vehicle Recommended Practice SAE J1939-71 (2003). Vehicle Application Layer. SAE International, Warrendale.
[17] De Lijn (2018). CO2-emissions of vehicles, General introduction in figures, from https://www.delijn.be/en/ overdelijn/organisatie/zorgzaam-ondernemen/milieu/co2uitstoot-voertuigen.html, accessed on 2018-03-30.

[18] De Lijn (2018). Emissions of our vehicle, from https://www. delijn.be/en/overdelijn/organisatie/zorgzaam-ondernemen/ milieu/uitstoot-voertuigen-delijn.html, accessed on 2018-0330.

[19] Lajunen, A. (2014). Energy consumption and cost-benefit analysis of hybrid and electric buses. Transportation Research Part C: Emerging Technologies, vol. 38, p. 1-15, D0l:10.1016/j. trc.2013.10.008.

[20] Mahmoud, M., Garnett, R., Ferguson, M., Kanaroglou, P. (2016). Electric buses: A review of alternative powertrains, Renewable and Sustainable Energy Reviews, vol. 62, p. 673684, D0l:10.1016/j.rser.2016.05.019.

[21] Hickman, A.J. (1999). Methodology for Calculating Transport Emissions and Energy Consumption. Project Report SE/491/98. Transport Research Laboratory, Berkshire. 